\title{
Alternative Complement Pathway in Anca- Associated Glomerulonephritis as a New Target for Treatment
}

\author{
Valeria Scaglioni* \\ Department of Rheumatology, Hospital Italiano de Buenos Aires, Argentina
}

Submission: March 10, 2017; Published: April 24, 2017

*Corresponding author: Valeria Scaglion, Department of Rheumatology, Hospital Italiano de Buenos Aires, Argentina, Tel: +54 1149590200 ;

Email: valeria.scaglioni@hospitalitalaino.org.ar

Keywords: ANCA vasculitis, Alternative complement pathway, Renal biopsy

\section{Introduction}

The Anti-neutrophil cytoplasmic antibody (ANCA)associated vasculitides are characterized by systemic vasculitis in combination with the presence of anti-neutrophil cytoplasmic antibodies [1]. ANCA-associated glomerulonephritis is considered "pauci-immune" with absent or mild glomerular tuft staining for immunoglobulin (Ig) and/or complement in renal biopsies. Because of this relative paucity of complement in vessels, complement system was not initially envisioned as an important participant in the pathogenesis of ANCA vasculitis and ANCA glomerulonephritis [2]. We recently published a paper were we evaluated the prevalence and clinical significance of immune deposits in ANCA-associated glomerulonephritis. The results showed that in a total of 53 patients, typical pauciimmune GN was found in 39 patients $(73.5 \%)$. In 14 patients $(26.4 \%)$ examination revealed substantial deposition of Ig or complement in the mesangium and/or along the glomerular capillary wall. The only difference comparing both groups was significantly higher proteinuria in patients with immune deposits. C3 deposition on the capillary wall was the most frequent finding (64.2\%), followed by $\mathrm{C} 3+\operatorname{IgG}(21.4 \%)$ and $\operatorname{IgG}$ alone (14.2\%). Normal serum complement C3 and C4 levels were observed in 50 patients (94.33\%), only 3 (5.6\%) were found to have slightly low levels. We did not find correlation between C3 deposits in renal tissue and levels of $\mathrm{C} 3$ in peripheral blood. One possible explanation could be that there is not immune complex deposition, but rather expression of activation of the alternative complement pathway, without real consumption of C3 [3].

There are several authors that have reported patients with ANCA glomerulonephritis with presence of glomerular immune deposits by electron microscopy or immunofluorescence [4-10].
In spite of these results, ANCA glomerulonephritis is still not consider an immune complex-mediated disease [11]. Besides that most patient with ANCA vasculitis are pauci immune, the fact

that up to $30 \%$ of patients have some degree of immune deposits, mainly C3, opened a new theory about the role of complement in the pathogenesis of the disease, with an important role in the activation of primed neutrophils by the component $\mathrm{C} 5 \mathrm{a}$ and the perpetuation of the inflammatory phenomenon thought the alternative complement pathway [3].

In terms of treatment, this new theory promoted new trials to test new drugs that block the $\mathrm{C} 5 \mathrm{a}$ receptor to prevent the activation of the alternative pathway [12].

\section{Conclusion}

In conclusion, now we have a new conception about the pathogenesis of ANCA vasculitis, we now are aware that some patients will have some degree of immune deposits in renal biopsies and most important, we will have the chance to use a new drug to block this pathway and improve the prognosis of the disease.

\section{References}

1. Kallenberg CGM, Heeringa P (2013) Complement is crucial in the pathogenesis of ANCA-associated vasculitis Complement is crucial in the pathogenesis of ANCA-associated vasculitis. Kidney Int 83(1): 1618.

2. Jennette JC, Falk RJ, Hu P, Xiao H (2013) Pathogenesis of Antineutrophil Cytoplasmic Autoantibody-Associated Small-Vessel Vasculitis. Annu Rev Pathol Mech Dis 8: 139-160.

3. Scaglioni V, Scolnik M, Catoggio LJ, Christiansen SB, Varela CF, et al. (2017) ANCA-associated pauci-immune glomerulonephritis: always pauci-immune? Clin Exp Rheumatol. 
4. Xing G, Chen M, Liu G, Heeringa P, Zhang J, (2009) Complement activation is involved in renal damage in human antineutrophil cytoplasmic autoantibody associated pauci-immune vasculitis. J Clin Immunol 29(3): 282-291.

5. Gou SJ, Yuan J, Chen M, Yu F, Zhao MH (2012) Circulating complement activation in patients with anti-neutrophil cytoplasmic antibodyassociated vasculitis. Kidney Int 83(1): 129-137.

6. Schreiber A, Xiao H, Jennette JC, Schneider W, Luft FC, et al. (2009) C5a receptor mediates neutrophil activation and ANCA-induced glomerulonephritis. J Am Soc Nephrol 20(2): 289-298.

7. Charles Jennette J, Xiao H, Hu P (2013) Complement in ANCAassociated vasculitis. Semin Nephrol 33(6): 557-564.

8. Haas M, Eustace J (2004) Immune complex deposits in ANCAassociated crescentic glomerulonephritis: A study of 126 cases. Kidney Int 65(6): 2145-2152.

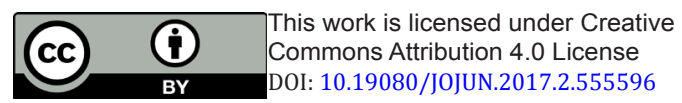

9. Yu F, Chen M, Wang SX, Zou WZ, Zhao MH, et al. (2007) Clinical and pathological characteristics and outcomes of Chinese patients with primary anti-neutrophil cytoplasmic antibodies-associated systemic vasculitis with immune complex deposition in kidney. Nephrology (Carlton) 12(1): 74-80.

10. Neumann I (2003) Glomerular immune deposits are associated with increased proteinuria in patients with ANCA-associated crescentic nephritis. Nephrol Dial Transplant 18(3): 524-531.

11. Chen M, Kallenberg CGM (2010) ANCA-associated vasculitides-advances in pathogenesis and treatment. Nat Rev Rheumatol 6(11): 653-664.

12. US National Library of Medicine. ClinicalTrials.gov.

\section{Your next submission with Juniper Publishers will reach you the below assets}

- Quality Editorial service

- Swift Peer Review

- Reprints availability

- E-prints Service

- Manuscript Podcast for convenient understanding

- Global attainment for your research

- Manuscript accessibility in different formats

(Pdf, E-pub, Full Text, Audio)

- Unceasing customer service

Track the below URL for one-step submission https://juniperpublishers.com/online-submission.php 